We thank Professor C. E. Dent, Professor F. V. Flynn, Dr. L. Watson, and Dr. D. Cusworth for their encouragement and advice. Dr. M. R. Lewin was very helpful and provided much constructive criticism. Mr. L. Freedman of the M.R.C. Statistical Research and Services unit helped extensively with the analysis of the data and its explanations. We acknowledge the help given by the laboratory technicians of ward 11 and the chemical pathology departm:nt of University College Hospital. We thank Miss A. Wickham for her excellent secretarial help and $\mathrm{Mr}$. V. Asta for the figures

Requests for reprints should be addressed to Dr. E. M. Birry, Department of Medicine B, Hadassah University Hospital, P.O.B. 499, Jerusalem, Israel.

\section{References}

Breen, M., and Freeman, S. (1961). Clinica Chima Acta, 6, 181

Dent, C. E (1962). British Medical fournal, 2, 1419, 1495.

Fanconi, A. and Rose, G. A. (1958). Ouarterly fournal of Medicine, 27, 463. Fourman, P., and Royer, P. (1968). Calcium Metabolism and the Bone, 2nd ed. p. 35. Oxford, Blackwell.

Flynn, F. V., Garcia-Webb, P., Healy, M. J. R., Macpherson, K., and Piper, K. A. (1973). Unpublished.
Gutman, A. B., and Gutman, E. B. (1937). Fournal of Clinical Investigation, $16,903$.

Halse, K. (1967). Technicon Symposia, ed. E. Kaweau, vol. 2, p. 143. New York, Mediad Incorporated.

Hanna, E. A., Nicholas, H. O., and Chamberlain, J. A. (1964). Clinical Chemistry, 10, 235

Hopkins, T., Howard, J. E., and Eisenberg, H. (1952). Bulletin of the fohn Hopkins Hospital, 91, 1 .

Loken, H. F., Havel, R. J., Gordan, G. S., and Whittington, S. L. (1960). fournal of Biological Chemistry, 235, 3654 .

McLean, F. C., and Hastings, A. B. (1935). fournal of Biological Chemistry,

Moore, E. W. (1971). Gastroenterology, 60, 43

Northam, B. E., and Widdowson, G. M. (1967). Technical Bulletin Association Clinical Biochemists, 11.

Orrell, D. H. (1971). Clinica Chimica Acta, 35, 483.

Pedersen, K. O. (1972). Scandinavian fournal of Clinical and Laboratory Investigation, 30, 191 .

Phillips, R. A., et al. (1950). Journal of Biological Chemistry, 183, 305.

Philpot, G. R. (1958). Ph.D. Thesis University of London, p. 114.

Prasad, A. S., and Flink, E. B. (1958). 7ournal of Laboratory and Clinical Medicine, 52, 1.

Toribara, T. Y., Terepka, A. R., and Dewey, P. A. (1957). fournal of Clinical Investigation, 36, 738 .

van Leeuwen, A. M., Thomasse, C. M., and Kapteyn, P. C. (1961). Clinica Chimica Acta, 6, 550 .

Varley, H. (1967). Practical Clinical Biochemistry, 4th edn., p. 242. London, Heinemann.

\title{
Interpretation of Serum Calcium in Patients with Abnormal Serum Proteins
}

\author{
R. B. PAYNE, A. J. LITTle, R. B. WILliaMS, J. R. MILNER
}

British Medical fournal, 1973, 4, 643-646

\section{Summary}

Two hundred consecutive specimens received in this laboratory for "liver function tests" showed a wide range of abnormal protein concentrations. Calcium concentration correlated closely with albumin $(r=0.867)$ but less closely with total protein $(r=0.682)$. A simple formula for adjusting calcium concentration was derived from the regression equation of calcium on albumin. Adjusted calcium $=$ calcium - albumin $+4 \cdot 0$, where calcium is in $\mathrm{mg} / 100 \mathrm{ml}$ and albumin in $\mathrm{g} / 100 \mathrm{ml}$.

Low calcium concentrations were found in $49(24.5 \%)$ and raised concentrations in six $(3 \%)$ of the 200 blood specimens taken for liver function tests. After adjustment, the $95 \%$ limits of the observed range were identical with the $95 \%$ limits of the normal range determined in this laboratory. Unlike adjustments based on total protein or specific gravity, the adjustment on albumin in 39 specimens which showed hypergammaglobulinaemia on electrophoresis gave normal calcium concentrations.

\section{Introduction}

The total calcium of serum or plasma is nearly all accounted for as calcium bound to protein and as calcium ions in roughly equal proportions, and it is the latter which are clinically

important (McLean and Hastings, 1935). Measurement of ionized or diffusible calcium is at present technically complex (Rose, 1972; Rushton et al., 1973), so that a screening procedure to detect patients with abnormal protein concentrations and to allow for the effect of changes in protein-bound calcium on the measurement of total calcium is desirable (Dent, 1962).

There are statistically significant correlations between calcium and total protein and between calcium and albumin in normal subjects, but the correlation coefficients are low (less than 0.4 ) and because of the limited ranges of the observed values the regression lines cannot be extrapolated with confidence to low protein concentrations (Keating et al., 1969; Williams et al., 1973). For this reason we have examined the relation between calcium and total protein and between calcium and albumin in patients who show a wide range of abnormalities of protein concentration but who are likely to have a low prevalence of disorders of calcium homoeostasis.

\section{Material and Methods}

Two hundred consecutive serum specimens received in the laboratory with a request for "liver function tests" but with no request for calcium estimation were analysed for calcium in addition to total protein and albumin on a Technicon S.M.A. Plus using cresolphthalein complexone for calcium, biuret for total protein, and bromocresol green in succinic acid buffer pH 4.2 for albumin. Duplicate analyses were not done. Measurements (in $\mathrm{mg} / 100 \mathrm{ml}$ and $\mathrm{g} / 100 \mathrm{ml}$ ) were made to one decimal place. The specimens included all those received from wards, outpatient departments, and general practitioners, but excluded those from the department of renal medicine in this hospital because many of their patients were receiving therapy which would affect calcium concentration. No account was taken of age, sex, or provisional diagnosis. The betweenbatch coefficients of variation at normal serum concentrations during the period of the investigation were $1.2 \%$ for calcium, 
$1.5 \%$ for total protein, and $3.5 \%$ for albumin. Cellulose acetate electrophoresis was carried out on all specimens.

\section{Results}

The calcium concentrations in the 200 specimens received for liver function tests ranged from $7 \cdot 1$ to $10 \cdot 8 \mathrm{mg} / 100 \mathrm{ml}$ (fig. 1). The $95 \%$ limits of the normal range determined in the laboratory shortly before the present investigation were 9.0 to 10.4 $\mathrm{mg} / 100 \mathrm{ml}$. Forty-nine $(24.5 \%)$ of the specimens had low calcium concentrations and six $(3 \%)$ had raised concentrations. The total protein concentrations ranged from 4.6 to $8.7 \mathrm{~g} / 100$ $\mathrm{ml}$ (normal range : 6.3 to $7.7 \mathrm{~g} / 100 \mathrm{ml}$ ), and the albumin concentrations ranged from 2.0 to $4.8 \mathrm{~g} / 100 \mathrm{ml}$ (normal range 3.7 to $4.7 \mathrm{~g} / 100 \mathrm{ml})$. Thirty-nine $(19.5 \%)$ of the specimens showed hypergammaglobulinaemia on electrophoresis.

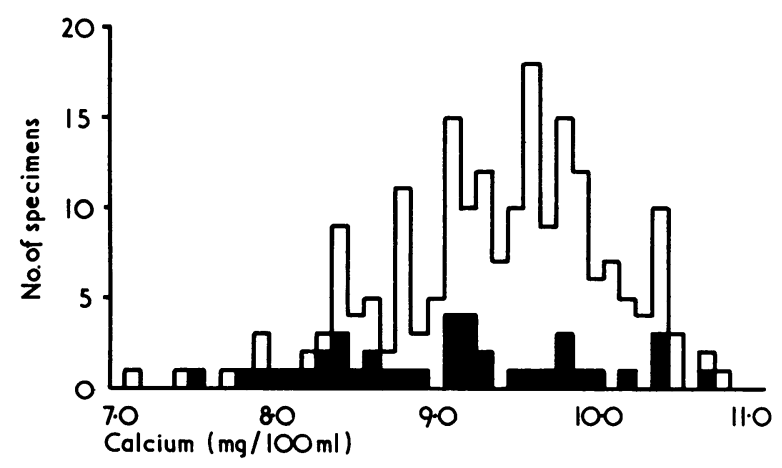

FIG. 1-Distribution of calcium concentrations in 200 specimens FIG. 1 -Distribution of calcium concentrations in 200 specimens
received for liver function tests. Solid areas represent hyperreceived for liver function
gammaglobulinaemic sera.

\section{RELATION BETWEEN CALCIUM AND TOTAL PROTEIN}

There was a significant correlation between calcium and total protein concentrations $(r=0.682 ; P<0.001)$. The regression equation of calcium on total protein was

$$
\text { Calcium }=(0.689 \times \text { total protein })+4.64
$$

(S.E. of regression coefficient 0.0849 ).

The calcium values were adjusted so that their mean was the same as the mean of the normal range $(9.70 \mathrm{mg} / 100 \mathrm{ml})$ by adding to the individual intercept values the difference between the mean intercept and the mean of the normal range by using the equation

$$
\text { Adjusted calcium }=\text { calcium }-(0.689 \times \text { total }
$$

$$
\text { protein) }+5.06 \ldots . . . . .1
$$

The derived $95 \%$ limits after applying this adjustment were 8.7 to $10.7 \mathrm{mg} / 100 \mathrm{ml}$ (table I). The 39 hypergammaglobulinaemic sera gave relatively low values within the overall distribution (fig. 2) and largely accounted for the unacceptable width of the range.

\begin{tabular}{|c|c|c|c|}
\hline & $\begin{array}{c}\text { Mean } \\
(\mathrm{mg} / 100 \mathrm{ml})\end{array}$ & $\begin{array}{c}\text { S.D. } \\
(\mathrm{mg} / 100 \mathrm{ml})\end{array}$ & $\begin{array}{c}95 \% \\
\text { Limits } \\
(\mathrm{mg} / 100 \mathrm{ml})\end{array}$ \\
\hline $\begin{array}{l}\text { Measured values } \\
\text { Values adjusted on total protein } \\
\text { (equation 1) } \\
\text { Values adjusted on albumin (equa- } \\
\text { tion 2) }\end{array}$ & $\begin{array}{l}9 \cdot 37 \\
9 \cdot 70 \\
9 \cdot 66\end{array}$ & $\begin{array}{l}0.698 \\
0.510 \\
0.347\end{array}$ & $\begin{array}{l}8 \cdot 0-10 \cdot 8 \\
8 \cdot 7-10 \cdot 7 \\
9 \cdot 0-10 \cdot 4\end{array}$ \\
\hline
\end{tabular}

TABLE I-Calcium Concentrations in 200 Specimens on zhich Liver Function Tests were Requested, before and after Adjustment for Protein Concentration

An adjustment suggested by Zilva and Pannall (1971) has since been slightly amended (J. F. Zilva, personal communica-

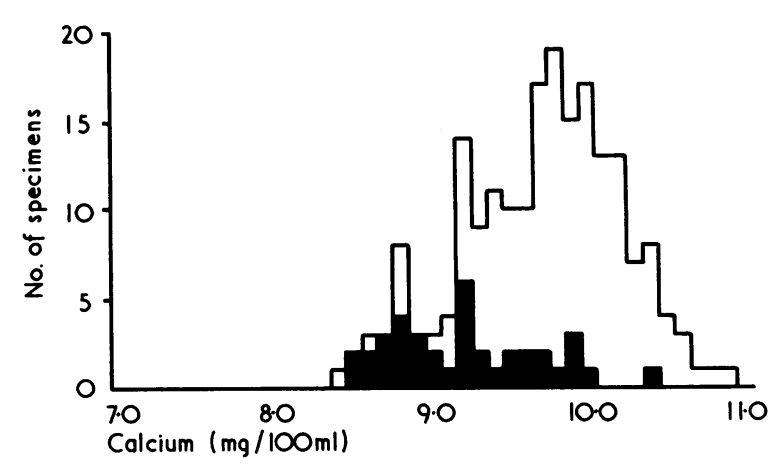

FIG. 2-Distribution of calcium concentrations in 200 specimens received for liver function tests, after adjustment of values for total protein concentration (equation 1). Solid areas represent hypergammaglobulinaemic sera.

tion, 1973). The modified formula is based on the specific gravity adjustment of Dent (1962) and the relation determined by Van Slyke et al. (1950), which was confirmed in Zilva's laboratory, between specific gravity and total protein: 0.25 $\mathrm{mg} / 100 \mathrm{ml}$ is added to the calcium for every $0.37 \mathrm{~g} / 100 \mathrm{ml}$ that the total protein is less than $7 \cdot 2 \mathrm{~g} / 100 \mathrm{ml}$, and vice versa. Thus

$$
\begin{array}{r}
\text { Adjusted calcium }=\text { calcium }-(0.676 \times \text { total } \\
\text { protein })+4.87
\end{array}
$$

This is similar to equation 1 above, and gave a similar wide range of adjusted values.

\section{RELATION BETWEEN CALCIUM AND ALBUMIN}

There was a highly significant correlation between calcium and albumin concentrations $(r=0.867 ; P<0.001)$ and the correlation coefficient was significantly greater than that of calcium on total protein $(P<0.001)$. The relation is shown in fig. 3. The regression equation of calcium on albumin was Calcium $=(0.989 \times$ albumin $)+5.70$

(S.E. of regression coefficient 0.0405).

The equation to adjust the calcium values so that their mean

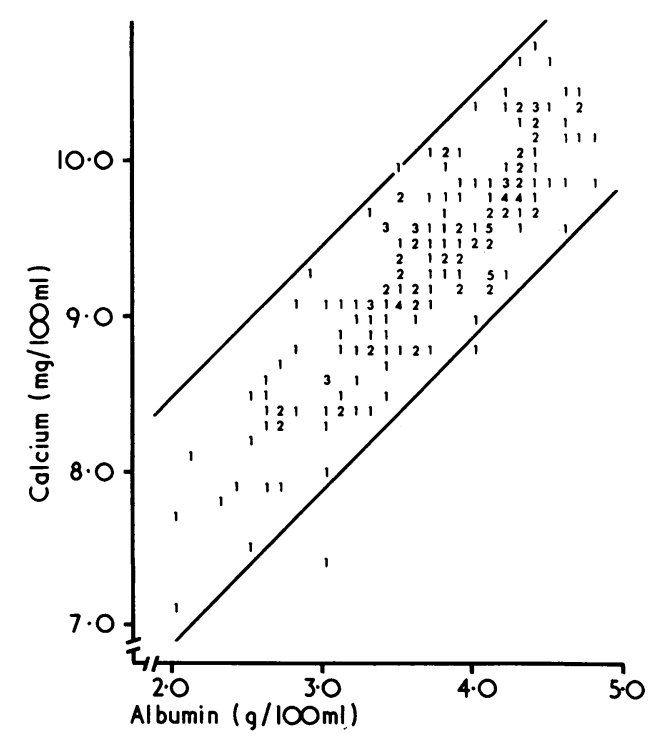

FIG. 3-Relation between calcium and albumin concentrations in 200 specimens received for liver function tests. 
was the same as the mean of the normal range $(9 \cdot 70 \mathrm{mg} / 100$ $\mathrm{ml}$ ) was

Adjusted calcium $=$ calcium $-(0.989 \times$ albumin $)+4.0$ or, with an error of less than $0.04 \mathrm{mg} / 100 \mathrm{ml}$ in the adjusted values at the mean of the normal range

Adjusted calcium $=$ calcium - albumin $+4.0 \ldots .2$ where calcium is in $\mathrm{mg} / 100 \mathrm{ml}$ and albumin in $\mathrm{g} / 100 \mathrm{ml}$. In S.I. units the equation becomes

Adjusted calcium $=$ calcium $-(0.25 \times$ albumin $)+1.0$ where calcium is in $\mathrm{mmol} / \mathrm{l}$. and albumin in $\mathrm{g} / \mathrm{l}$.

The distribution of adjusted calcium values after applying equation 2 is shown in fig. 4. The range of values in the hypergammaglobulinaemic sera was similar to that of the group as a whole, and the $95 \%$ limits of the overall distribution, 9.0 to $10.4 \mathrm{mg} / 100 \mathrm{ml}$, were identical with those of the normal range (table I).

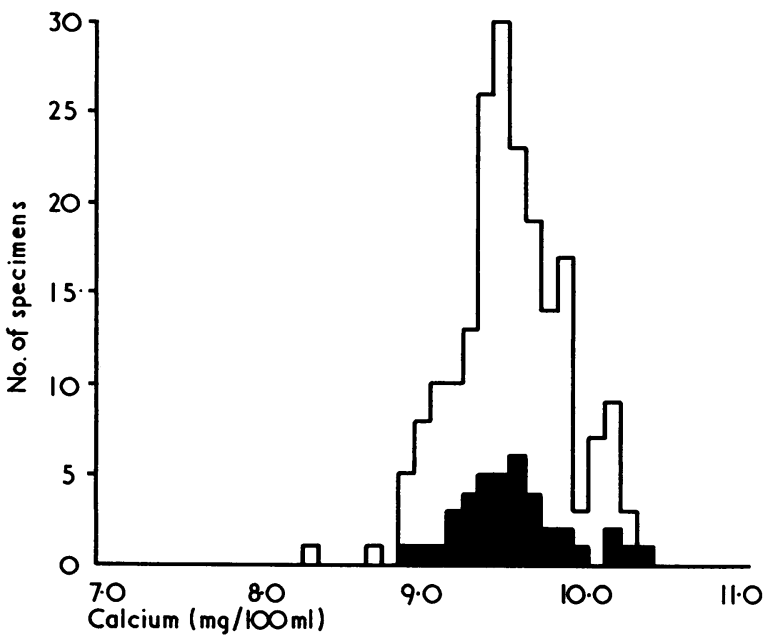

FIG. 4-Distribution of calcium concentrations in 200 specimens received for liver function tests after adjustment of values for albumin concentration (equation 2). Solid areas represent hypergammaglobulinaemic sera.

The procedure suggested by Orrell (1971) was also applied to the data. This is based on adjustment to his "mean inpatient albumin concentration" of $3.4 \mathrm{~g} / 100 \mathrm{ml}$, using the equation

Adjusted calcium $=$ calcium -0.7 (albumin -3.4 ).

This gave a similarly narrow but much lower range (mean 9.15; S.D. $0.387 ; 95 \%$ limits 8.4 to $9.9 \mathrm{mg} / 100 \mathrm{ml}$ ). Fiftysix $(28.0 \%)$ of the adjusted values fell below the lower $95 \%$ limit of the normal range of this laboratory.

\section{REQUESTS FOR CALCIUM ANALYSIS}

A prospective study was made of 100 consecutive sera received in the laboratory with a request for calcium analysis, again excluding requests from the department of renal medicine. Additional measurements of total protein and albumin were made on all the sera, and electrophoresis was carried out. Adjustments of calcium concentration for total protein and albumin were made by using equations 1 and 2 above, derived from data on sera received for liver function tests.

The prevalence of abnormal protein concentrations in these specimens was surprisingly high. Of the 100 sera 19 had abnormal total protein concentrations and 17 had abnormal albumin concentrations. The frequency of low and raised calcium concentrations before and after adjustment for total protein and for albumin is shown in table II. Seven of the sera had hypergammaglobulinaemia on electrophoresis. Of these five had low calcium concentrations; four remained low after adjustment for total protein but none after adjustment for albumin concentration.
TABLE II-Calcium Concentrations in 100 Specimens on which Calcium Analysis was Requested, before and after Adjustment for Protein Concentration

\begin{tabular}{ll|c|c}
\hline & & $\begin{array}{c}\text { Low } \\
\text { Values } \\
(<9 \cdot 0 \\
\mathrm{mg} / 100 \mathrm{ml})\end{array}$ & $\begin{array}{c}\text { Raised } \\
\text { Values } \\
(>10 \cdot 4 \\
\mathrm{mg} / 100 \mathrm{ml})\end{array}$ \\
\hline $\begin{array}{ll}\text { Measured values } \\
\begin{array}{l}\text { Values adjusted on total protein (equation } \\
\text { Values adjusted on albumin (equation 2) }\end{array}\end{array}$ & $\cdots$ & 22 & 2 \\
\hline
\end{tabular}

All the calcium values which remained low after adjustment for albumin, $9 \%$ of the total, were consistent with the provisional diagnoses and other biochemical measurements. The three adjusted values which were raised were all from patients with carcinoma of the breast. One of these had been at the upper limit of normal before adjustment.

\section{Discussion}

A number of factors may alter the protein content of serum, and therefore the total calcium concentration, without necessarily affecting the non-protein bound, largely ionized, fraction. These include diseases in which the synthesis of serum proteins is increased or decreased, or in which there is increased protein loss; prolonged venous occlusion which may cause "ultrafiltration" of blood in the capillaries of the forearm (van Leeuwen et al., 1961); and alterations of posture, which may cause shifts of fluid into or out of the intravascular compartment (Fawcett and Wynn, 1960)

Dent and Watson (1968) emphasized that the adjustment of total calcium concentration for changes in protein by using specific gravity measurements is inaccurate and should not be applied if electrophoresis shows the protein distribution to be abnormal. We have shown that adjustment for total protein concentration is unsatisfactory in patients with hypergammaglobulinaemia, and that abnormal globulin concentrations are not uncommon in patients with diagnostic problems concerned with calcium metabolism.

The present investigation was carried out on serum specimens on which liver function tests but not calcium had been requested, because we thought there would be a high prevalence of abnormal protein concentrations but a low prevalence of disorders of calcium homoeostasis. The data support this view: the $95 \%$ limits of the calcium concentrations after adjustment for the regression of calcium on albumin were identical with the limits of the normal range in healthy persons, and the Gaussian shape of the distribution suggests that contamination with calcium values of diagnostic significance was minimal (cf. Cook et al., 1970).

Our regression coefficient of calcium on total protein $(0.689)$ is of the same order as the regression coefficient derived from the calcium adjustment of Dent (1962) based on specific gravity (0.676). However, our regression coefficient of calcium on albumin, 0.989 , is considerably higher than the coefficient of 0.707 determined by Orrell (1971) on 954 specimens received in his laboratory either for albumin or for calcium determination, though our relation between calcium and albumin is of the same order as that shown graphically by Jones et al. (1967) in patients with such disorders as malabsorption syndrome, cirrhosis, and malnutrition, and by Cockel et al. (1971) in patients with rheumatoid arthritis.

There are two factors which might have contributed to this discrepancy. The first is that the series of Orrell (1971), unlike the present series, is likely to have included specimens from patients with the nephrotic syndrome. There is evidence that such patients have higher calcium levels than patients with the same degree of hypoalbuminaemia from other causes (Danowski et al., 1957; Jones et al., 1967), possibly due to the presence in nephrotic sera of other macromolecules which bind calcium more effectively than albumin (Pedersen, 1972). 
The second factor is that Orrell's regression coefficient was based on specimens on which either albumin or calcium estimation had been requested, and so would have included some abnormal calcium values not due to protein abnormalities. In our experience true hypocalcaemia is more common than hypercalcaemia. Thus his data would have been weighted with low albumin values associated with relatively higher calcium values from patients with the nephrotic syndrome and with low calcium values with normal albumin values from patients with, for example, osteomalacia. These differences would account both for our higher regression coefficient and for our higher correlation coefficient $(0.867$ on 200 pairs compared with his of 0.720 on 954 pairs: $P<0.001)$. Our intercept at zero albumin concentration $(5.7 \mathrm{mg} / 100 \mathrm{ml})$ is closer to reported values for normal plasma ultrafiltrable calcium (Robertson, 1969; Pedersen, 1970; Rose, 1972) than the intercept calculated from Orrell's (1971) data $(6.8 \mathrm{mg} / 100 \mathrm{ml})$.

Our equation for adjusting calcium concentration by using measurements of albumin

Adjusted calcium $=$ calcium - albumin $+4 \cdot 0$ was based on correction to the mean normal calcium concentration rather than to the mean normal albumin concentration because the between-batch coefficients of variation at normal serum concentrations were $1.2 \%$ for calcium and $3.5 \%$ for albumin, so that we had greater confidence in the accuracy of the mean normal calcium concentration. The adjustment is easily remembered: the measured calcium concentration is increased by $0.1 \mathrm{mg} / 100 \mathrm{ml}$ for every $0.1 \mathrm{~g} / 100$ $\mathrm{ml}$ that the albumin concentration is below $4.0 \mathrm{~g} / 100 \mathrm{ml}$, and vice versa. It should be noted that the adjustment cannot be applied to calcium values on patients with the nephrotic syndrome and hypoalbuminaemia, for the reasons discussed above, nor can it be applied to data from another laboratory if the accuracy and precision of calcium and albumin measurements, and therefore the normal ranges, differ greatly from ours (Payne, 1973).
We conclude that it is impossible to interpret a patient's serum calcium concentration without some measurement of protein concentration, and that any adjustment which is made shou!d be based on albumin rather than total protein or specific gravity.

We are grateful to Dr. Brian Morgan and Dr. Joan Zilva for helpful discussion.

\section{References}

Cockel, R., Kendall, M. J., Becker, J. F., and Hawkins, C. F. (1971). Annals of the Rheumatic Diseases, 30, 166.

Cook, M. G., Levell, M. J., and Payne, R. B. (1970). Fournal of Clinical Pathology, 23, 778 .

Danowski, T. S., et al. (1957). American fournal of Diseases of Children, 93, 604.

Dent, C. E. (1962). British Medical fournal, 2, 1419.

Dent, C. E., and Watson, L. (1968). Lancet, 2, 662 .

Fawcett, J. K., and Wynn, V. (1960). Fournal of Clinical Pathology, 13, 304

Jones, J. H., Peters, D. K., Morgan, D. B., Coles, G. A., and Mallick, N. P.

(1967). Quarterly fournal of Medicine, 36, 301.

Mournal of Laboratory and Clinical Medicine, 73, 825. Sciences, $189,21$.

Orrell, D. H. (1971). Clinica Chimica Acta, 35, 483.

Payne, R. B. (1973). Lancet, 2, 375.

Pedersen, K. O. (1970). Scandinavian fournal of Clinical and Laboratory

Investigation, 25, 223. Scandinavian fournal of Clinical and Laboratory
Pedersen, K. O. (1972). Scan Investigation, 30, 321.

Robertson, W. G. (1969). Clinica Chimica Acta, 24, 149.
Rose, G. A. (1972). Clinica Chimica Acta, 37, 343.

Rushton, M. L., Sammons, H. G., Gosling, P., and Robinson, B. H. B. (1973). Annals of Clinical Biochemistry, 10, 63.

van Leeuwen, A. M., Thomasse, C. M., and Kapteyn, P. C. (1961). Clinica Chimica Acta, 6, 550.

Van Slyke, D. D., et al. (1950). Fournal of Biological Chemistry, 183, 331.

Williams, R. B., Annan, W. Isherwood, D. M. Levell, M. J. and Payne, R. B. (1971). Unpublished observations.

Zilva, J. F., and Pannall, P. R. (1971). Clinical Chemistry in Diagnosis and Treatment, p. 198. London, Lloyd-Luke.

\title{
Dermatoglyphics in Children with Acute Leukaemia
}

\author{
S. G. PURVIS-SMITH, MARGARET A. MENSER
}

British Medical fournal, 1973, 4, 646-648

\section{Introduction}

\section{Summary}

The dermatoglyphics of 135 children with acute leukaemia differed significantly from those of normal controls, and examination of 174 of the patients' first degree relatives indicated that familial factors were involved. The findings suggested that within the racial group studied dermatoglyphics may partly identify a population subgroup which is at increased risk of leukaemogenesis. While these observations may not have immediate clinical application, they are likely to contribute to a greater understanding of individuals who have increased constitutional susceptibility to leukaemia.

\footnotetext{
Children's Medical Research Foundation, Royal Alexandra Hospital for Children, Sydney, Australia

S. G. PURVIS-SMITH, B.sC., Research Assistant

MARGARET A. MENSER, M.D., F.R.A.C.P., Norman Gregg Research Fellow
}

Though there have been a number of apparently conflicting studies on the fingerprints and handprints (dermatoglyphics) of patients with leukaemia (Aleksandrowicz et al., 1966; Kobayashi et al., 1968; Carvalho, 1969; Menser and Purvis-Smith, 1969, 1972; Nora et al., 1969; Rosner, 1969, 1970; Wertelecki et al., 1969, 1973; Stowens and Sammon, 1970; Verbov, 1970; Wittwer and Giessmann, 1970; Zahálková and Běluła, 1970; Berka et al., 1971), careful review of the reports suggests that the dermatoglyphics of children with acute leukaemia deviate fairly consistently from normal. Such findings, if confirmed, may be valuable in identifying populations with increased susceptibility to leukaemogenesis.

\section{Subjects and Methods}

Handprints were obtained from 135 Caucasian children (77 males, 58 females) with a proved diagnosis of either acute lymphatic leukaemia or acute blast cell leukaemia. The patients ranged in age from 4 months to 15 years; the mean age at onset of the disease was 5.26 years in the males and 5.38 years in the females. The patient group included those from earlier studies 